\title{
Pengaruh Pengetahuan, Sikap, dan Tindakan Masyarakat Terhadap Keberadaan Rumah Kelola Sampah Menggunakan Metode SEM (Studi Kasus: Keluarahan Tangkerang Barat)
}

\author{
Dewi Diniaty ${ }^{1}$, Ekie Gilang Permata ${ }^{2}$, Ismi Dwi Alpian ${ }^{3}$ \\ 1,2 Jurusan Teknik Industri, Fakultas Sains dan Teknologi, UIN Sultan Syarif Kasim Riau \\ Jl. HR. Soebrantas No. 155 Simpang Baru, Panam, Pekanbaru, 28293 \\ Email: dewidiniaty@uin-suska.ac.id, ismidwialpiann@yahoo.com
}

\begin{abstract}
ABSTRAK
Kelurahan Tangkerang Barat merupakan salah satu kelurahan yang ada di Kecamatan Marpoyan Damai Kota Pekanbaru. Kelurahan Tangkerang Barat tepatnya di RW 004 RT 006 terdapat Rumah Kelola Sampah (RKS). RKS memiliki upaya untuk mengelola sampah rumah tangga dengan membentuk program Rumah Kelola Sampah. RKS ini dilakukan edukasi percobaan di 10 rumah warga. Setelah dilakukan edukasi pecobaan, hanya 3 rumah warga yang bersedia mengikuti program RKS. Hal ini disebabkan karena kurangnya minat masyarakat dalam melakukan pengelolaan sampah sehingga menyebabkan tingkat keberhasilan program RKS belum maksimal. Penelitian ini bertujuan untuk mengetahui pengaruh pengetahuan masyarakat terhadap keberadaan RKS, mengetahui pengaruh sikap masyarakat terhadap keberadaan RKS, mengetahui pengaruh tindakan masyarakat terhadap keberadaan RKS, memberikan rancangan usulan perbaikan di RKS. Metode yang digunakan pada penelitian ini adalah metode Structural Equation Modeling (SEM) untuk menggambarkan keterkaitan hubungan antara variabel pengamatan (indikator) dan variabel laten. Hasil penelitian menunjukkan bahwa variabel pengetahuan masyarakat, sikap masyarakat, dan tindakan masyarakat berpengaruh positif dan signifikan terhadap keberadaan RKS. Hal ini dibuktikan dengan hipotesis dapat diterima apabila nilai probabilitas (P) sebesar < 0,05 dan nilai Critical Ratio (CR) sebesar $>1,96$. Usulan perbaikan pada RKS yaitu melakukan pelatihan atau penyuluhan terhadap masyarakat tentang pengolahan sampah menjadi produk yang bermanfaat sehingga dapat meningkatkan minat dan partisipasi masyarakat.
\end{abstract}

\section{Pendahuluan}

Salah satu permasalahan besar yang dialami kota-kota besar di Indonesia adalah persampahan. Sampah dapat diartikan sebagai konsekuensi adanya aktivitas kehidupan manusia. Tidak dapat dipungkiri, sampah akan selalu ada selama aktivitas kehidupan masih terus berjalan. Setiap tahunnya, dapat dipastikan volume sampah akan selalu bertambah seiring dengan pola konsumerisme masyarakat yang semakin meningkat.

Pertumbuhan penduduk di kawasan permukiman perkotaan menimbulkan permasalahan pengelolaan sampah mulai dari masalah timbulan sampah, kebutuhan tempat pemrosesan akhir sampah, serta biaya lingkungan yang ditimbulkan. Untuk dapat mengurangi jumlah sampah yang masuk ke TPA, pemerintah daerah membuat program rumah pengelolaan sampah yang bertujuan untuk mengurangi tumpukan sampah yang semakin hari semakin bertambah sehingga dapat mengurangi timbunan sampah yang menganggu kesehatan.

Kelurahan Tangkerang Barat merupakan salah satu kelurahan yang ada di Kecamatan Marpoyan Damai. Jumlah penduduk di Kelurahan Tangkerang Barat tahun 2016 mencapai 19.632 jiwa. Luas wilayah Kelurahan Tangkerang Barat adalah 5,35 $\mathrm{km}^{2}$. Salah satu kelurahan di Marpoyan Damai yang memiliki upaya untuk mengelola sampah yang dibantu oleh PT. HERO Supermarket Grup yaitu Kelurahan Tangkerang Barat tepatnya di RW 004 RT 006. PT. HERO Supermarket Grup membentuk Rumah kelola Sampah (RKS) dengan tujuan untuk membantu pemerintah dalam mengedukasi masyarakat tentang pengelolaan 
secara terpadu dan tepat guna, serta meningkatkan ekonomi masyarakat.

Rumah kelola Sampah (RKS) adalah suatu wadah yang berperan dalam mengelola sampah rumah tangga dan sejenisnya dalam upaya pengurangan ataupun penanganan sampah sehingga mengurangi dampak penumpukan dan pencemaran sampah. Rumah Kelola Sampah (RKS) berfungsi mengelola sampah yang ada di masyarakat dan dikelola menjadi produk yang berguna bagi masyarakat. PT. Hero Supermarket Group membuat suatu program pola pengelolaan sampah berbasis masyarakat yang dilakukan untuk 10 rumah masyarakat. 10 rumah tersebut di fasilitaskan komposter. 10 rumah melakukan pengelolaan sampah organik menjadi pupuk yang digunakan untuk tanaman hidroponik. Apabila program ini berhasil PT. Hero Supermarket Group akan memfasilitaskan Rumah Kelola Sampah (RKS) dalam jangka panjang.

Upaya yang dilakukan oleh masyarakat Kelurahan Tangkerang Barat antara lain dengan cara memilah sampah berdasarkan sifatnya, sampah organik dan anorganik. Sampah yang sudah dipilah dimasukkan kedalam komposter dan di hendapkan selama beberapa hari. Hasil dari hendapan tersebut akan berair dan cairan samapah tersebut akan menjadi pupuk organik cair. Sedangkan sampah yang bersifat anorganik belum dilakukan pengolahan, karena program Rumah Kelola Sampah (RKS) untuk tahun pertama hanya mengelola sampah organik.

Berdasarkan hasil observasi dan wawancara yang telah dilakukan bahwa Program RKS dari 10 rumah yang telah diedukasi, hanya 3 rumah warga saja yang bersedia mengikuti program RKS. Kemudian, sampah yang dikelola untuk dijadikan pupuk hanya menggunakan jenis sampah dari kulit nenas saja dan masyarakat belum memanfaatkan jenis sampah yang lain. Selanjutnya RKS belum memiliki pengelolaan manajemen yang baik dikarenakan struktur organisasi yang masih belum lengkap. Hal ini disebabkan karena kurangnya minat masyarakat Kelurahan Tangkerang Barat dalam melakukan pengelolaan sampah di RKS sehingga menyebabkan tingkat keberhasilan program dari Rumah Kelola Sampah (RKS) belum maksimal.

Untuk mengetahui pengaruh pengetahuan, sikap, dan tindakan masyarakat di Kelurahan Tangkerang Barat terhadap keberadaan Rumah Kelola Sampah (RKS) maka dilakukan penyebaran kuesioner pendahuluan terhadap 30 responden di Kelurahan Tangkerang Barat. Berikut ini adalah grafik tanggapan responden terhadap keberadaan Rumah Kelola Sampah (RKS) di Kelurahan Tangkerang Barat yang dapat dilihat pada gambar 1.1 .

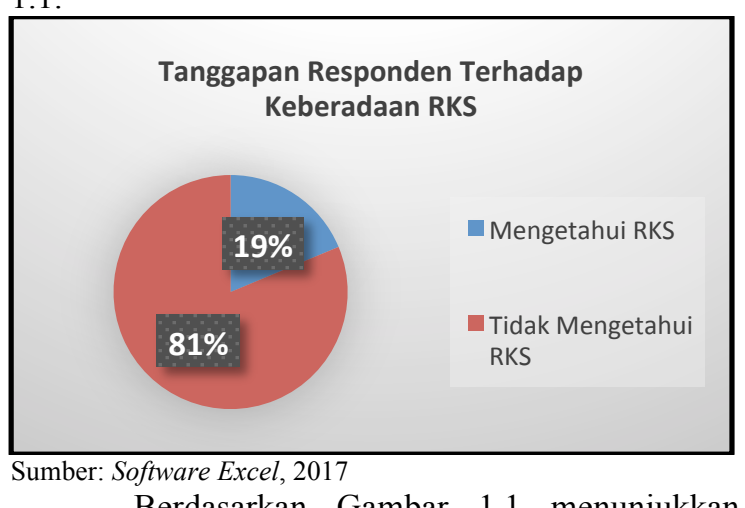
bahwa dari 30 responden 23 orang (81\%) tidak mengetahui tentang keberadaan Rumah Kelola Sampah (RKS). Hal ini menunjukkan bahwa sebagian besar masyarakat di Kelurahan Tangkerang Barat belum mengetahui adanya Rumah Kelola Sampah (RKS) serta kurangnya minat masyarakat dalam melakukan pengelolaan sampah.

Penelitian ini bertujuan untuk mengetahui pengaruh pengetahuan masyarakat, sikap masyarakat, dan tindakan masyarakat terhadap keberadaan Rumah Kelola Sampah (RKS) dan memberikan rancangan usulan perbaikan yang dilakukan di Rumah Kelola Sampah (RKS) dalam upaya meningkatkan minat masyarakat dalam melakukan pengelolaan sampah.

\section{Tinjauan Pustaka}

\section{Sampah}

Sampah dapat di definisikan sebagai semua buangan yang dihasilkan dari aktivitas manusia dan hewan yang berupa padatan, yang dibuang karena sudah tidak berguna atau diperlukan lagi. Sedangkan menurut WHO, sampah adalah sesuatu yang tidak digunakan, tidak dipakai, tidak disenangi atau sesuatu yang dibuang berasal dari kegiatan manusia dan tidak terjadi dengan sendirinya (Fadhilah dkk, 2013).

Di dalam UU No. 18 Tahun 2008 Tentang Pengelolaan Sampah disebutkan bahwa sampah adalah sisa kegiatan sehari-hari manusia dan atau proses alam yang berbentuk padat. Menurut SNI 192454-2002, sampah adalah limbah yang bersifat padat terdiri dari zat organik dan zat anorganik yang dianggap tidak berguna lagi dan harus dikelola agar tidak membahayakan lingkungan dan melindungi 
investasi pembangunan. Sampah adalah limbah yang berbentuk padat dan juga setengah padat, dari bahan organik atau anorganik, baik benda logam maupun benda bukan logam, yang dapat terbakar dan yang tidak dapat terbakar. (Ikhsandri, 2014).

Pengetahuan Masyarakat Terhadap Sampah Menurut Notoatmodjo (2003), pengetahuan adalah hasil dari tahu, dan ini terjadi setelah orang melakukan penginderaan terhadap suatu objek tertentu. Maka dapat disimpulkan bahwa pengetahuan tentang sampah yaitu masyarakat mendapatkan hasil dari penginderaan terkait dengan pengelolaan sampah yang meliputi jenis-jenis sampah, sumber-sumber sampah, pengolahan sampah dan keuntungan serta kerugian sampah (Garini, 2012).

Faktor-faktor yang mempengaruhi tingkat pengetahuan seseorang antara lain yaitu (Hombing, 2015):

1. Umur

2. Pendidikan

3. Pekerjaan

4. Lama Bekerja

\section{Sikap Masyarakat Terhadap Sampah}

Sikap adalah bentuk pernyataan seseorang terhadap hal-hal yang ditemuinya, seperti benda, orang ataupun fenomena. Sikap ini membutuhkan stimulus untuk menghasilkan respon. Adapun output sikap ini akan sangat tergantung pada stiap individu, apabila individu tersebut tertarik maka ia akan mendekat dan apabila tidak suka maka ia akan merespon sebaliknya. Sikap merupakan perasaan mendukung atau memihak (favourable) maupun perasaan tidak mendukung (unfavourable) pada suatu objek. Istilah sikap atau attitude pada awalnya digunakan untuk menunjukkan status mental individu. Sikap individu diarahkan pada suatu hal atau objek tertentu dan masih bersifat tertutup. Sikap dapat menuntun perilaku kita sehingga kita akan bertindak sesuai dengan sikap yang kita ekspresikan. Kesadaran individu untuk menentukan tingkah laku nyata dan perilaku yang mungkin terjadi itulah yang dimaksud dengan sikap (Hombing, 2015).

\section{Tindakan Masyarakat Terhadap Sampah}

Teori tindakan merupakan suatu teori dalam memahami tindakan yang perlu dilakukan untuk mendapatkan hasil yang diinginkan dalam suatu keadaan. Ketika tindakan sudah menjadi kebiasaan, maka secara otomatis tindakan itu akan selalu dijalankan. Namun ketika tindakan sudah tidak efektif maka akan muncul kepedulian pada teori tindakan serta usaha untuk memperbaikinya (Hombing, 2015).

\section{Structural Equation Modeling (SEM)}

Dalam teknik statistik kita mengenal apa yang dinamakan Structural Equation Modeling (SEM). SEM adalah suatu teknik statistik yang mampu menganalisis pola hubungan antara konstrak laten dan indikatornya, konstrak laten yang satu dengan lainnya, serta kesalahan pengukuran secara langsung. SEM merupakan keluarga statistik multivariate dependent. SEM memungkinkan dilakukan analisis diantara beberapa variabel dependent dan independent secara langsung (Yamin, 2009).

Alasan yang mendasari digunakan SEM adalah Pertama, SEM mempunyai kemampuan untuk mengestimasi hubungan antarvariabel yang bersifat multiple relationship. Hubungan ini dibentuk dalam model struktual (hubungan antara konstrak dependent dan independent). Kedua, mempunyai kemampuan untuk menggambarkan pola hubungan antara konstrak laten (Unobserved) dan variabel manifest (manifest variable atau variabel indikator). Dalam perkembangannya, pengolah data untuk analisis SEM menjadi mudah dengan bantuan beberapa perangkat lunak (Software) statistik, seperti Lisrel, AMOS, dan Smart PLS.Uji realibilitas dalam SEM dihitung dengan rumus sebagai berikut (Purwanti, 2015):

C.R $=(\Sigma$ Std. Loading $) 2 /(\Sigma$ Std. Loading $) 2+\Sigma$ $\epsilon j$

untuk membuat pemodelan yang lengkap, perlu dilakukan langkah langkah sebagai berikut (Rahman, 2016):

1. Pengembangan Model Berbasis Teori

Langkah pertama dalam pengembangan model SEM adalah pencarian atau pengembangan model yang mempunyai justifikasi teoritis yang kuat. Seorang peneliti harus melakukan serangkaian telaah pustaka yang intens guna mendapatkan justifikasi atas model teoritis yang dikembangkan.

2. Pengembangan Diagram Alur (Path Diagram) Path diagram akan mempermudah peneliti melihat hubungan-hubungan kausalitas yang ingin diuji. Peneliti biasanya bekerja dengan "construk" atau "factor" yaitu konsep-konsep yang memiliki pijakan teoritis yang cukup untuk menjelaskan berbagai bentuk hubungan. Konstruk-konstruk yang dibangun dalam diagram alur dapat dibagi menjadi dua kelompok, yaitu konstruk eksogen dan konstruk endogen 
3. Konversi diagram alur ke dalam serangkaian persamaan struktural dan spesifikasi model pengukuran

peneliti dapat mulai mengkonversi spesifikasi model tersebut kedalam rangkaian persamaan. Persamaan yang akan dibangun terdiri dari Persamaan spesifikasi model pengukuran yaitu menentukan serangkaian matriks yang menunjukkan korelasi yang dihipotesiskan antar konstruk atau variabel.

4. Menginterpretasikan dan Memodifikasi Model Langkah terakhir dalam SEM adalah menginteprestasikan dan memodefikasi model, khususnya bagi model-model yang tidak memenuhi syarat dalam proses pengujian yang dilakukan. Setelah model diestimasi, residualnya haruslah kecil atau mendekati nol dan distribusi frekuensi dari kovarians residual harus bersifat simetrik.

Keunggulan-keunggulan SEM dibanding dengan regresi berganda antara lain (Kasanah, 2015):

1. Memungkinkan adanya asumsi-asumsi yang lebih fleksibel

2. Penggunaan analisis faktor penegasan (confirmatory factor analysis) untuk mengurangi kesalahan pengukuran dengan memiliki banyak indikator dalam satu variabel laten

3. Daya tarik interface pemodelan grafis untuk memudahkan pengguna membaca keluaran hasil analisis

4. Kemungkinan adanya pengujian model secara keseluruhan dari pada koefisien-koefisien secara sendiri-sendiri

5. Kemampuan untuk menguji model-model dengan menggunakan beberapa variabel terikat

6. Kemampuan untuk membuat model terhadap variabel-variabel perantara

7. kemampuan untuk membuat model gangguan kesalahan (error term)

8. kemampuan untuk menguji koefisien-koefisien diluar antara beberapa kelompok subjek

9. kemampuan untuk mengatasi data yang sulit, seperti data time series dengan

\section{Software AMOS}

Kemajuan teknologi informasi, khususnya dalam pengembangan pembuatan software, telah mendorong munculnya software khusus untuk perhitungan alat statistik dasar dari SEM yaitu salah satunya software AMOS.AMOS mulai populer digunakan, baik oleh kalangan peneliti, akademisi, maupun para praktisi. Kelebihan software AMOS terutama ada pada sifat software yang user friendly, sehingga dapat digunakan bagi para pemula dibidang SEM sekalipun. Ada dua tahapan penggunaan AMOS yaitu (Santoso, 2015):

1. Membuat model berdasarkan teori tertentu

2. Menguji apakah sampel data yang kemudian dikumpulkan apakah sesuai (fit) dengan model teoritis yang ada

\section{Metode Penelitian}

Metode penelitian merupakan langkahlangkah yang dilalui dalam melakukan penelitian. Adapun tahapan dapat dilihat pada Gambar 3.1

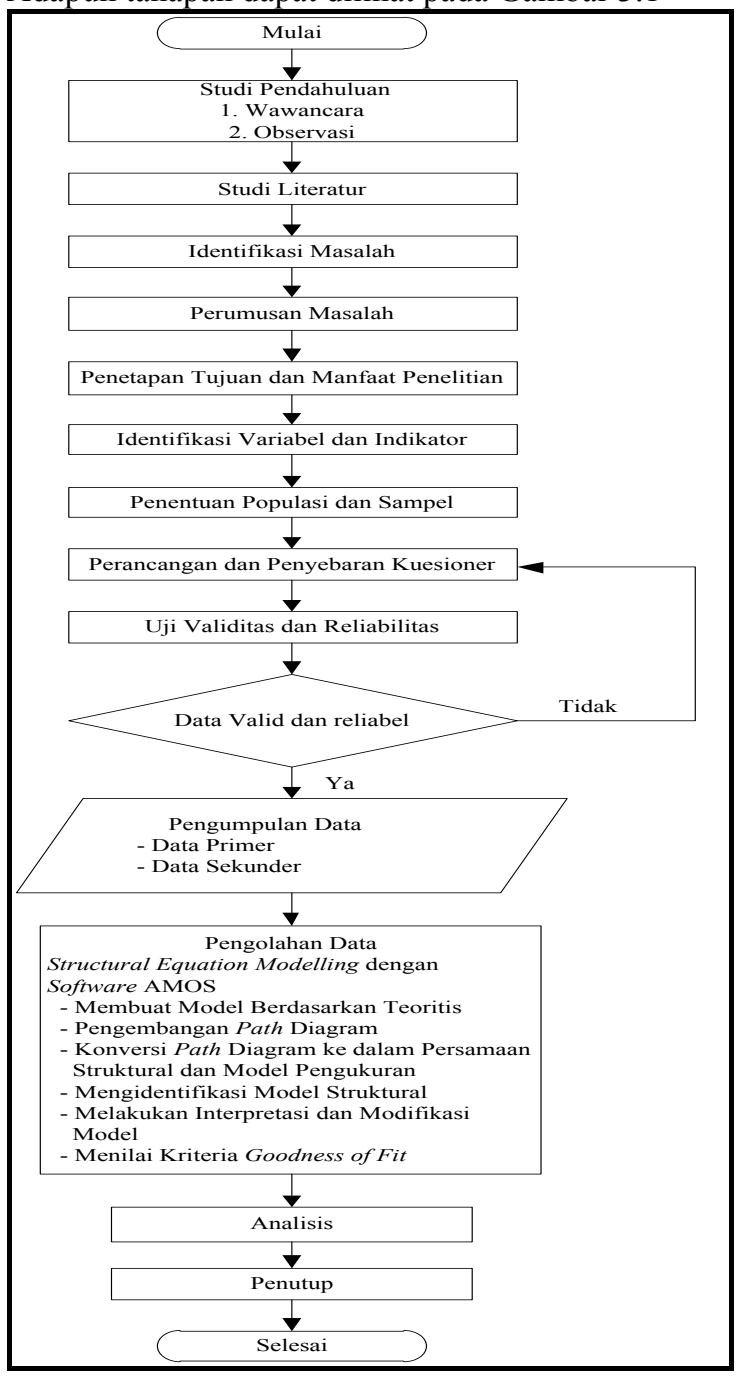

Gambar 3.1 Flowchart Penelitian 


\section{Hasil dan Pembahasan}

\section{Membuat Model Berdasarkan Teoritis}

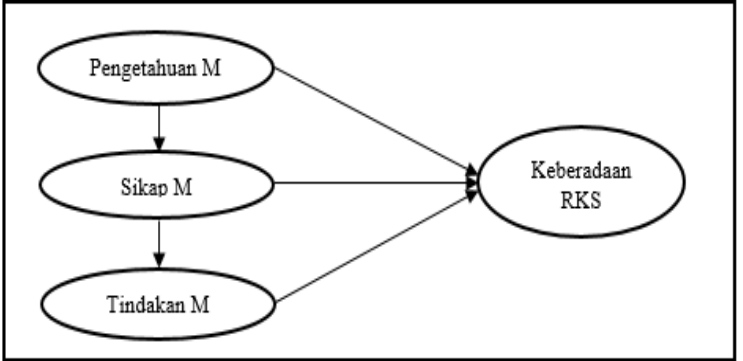

Gambar 4.1 Model Konseptual

Pada gambar 4.1 secara umum model tersebut terdiri atas 3 variabel independen dan 1 variabel dependen. Variabel independen adalah pengetahuan masyarakat, sikap masyarakat, dan tindakan masyarakat. Sedangan variabel dependen adalah keberadaan RKS.

\section{Pengembangan Path Diagram}

Model teoritis yang telah dibuat selanjutnya digambarkan kedalam sebuah path diagram, untuk mempermudah peneliti melihat hubungan-hubungan kausalitas yang ingin diuji. Path diagram merupakan representasi visual dari sebuah model yang menggambarkan seluruh hubungan antara variabel-variabel yang ada didalamnya. Pengembangan Path Diagram dapat dilihat pada gambar berikut ini:

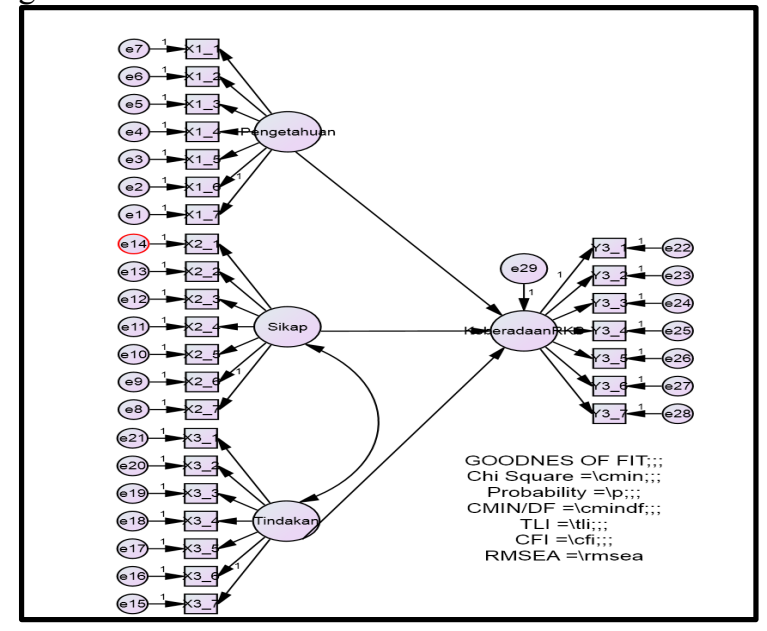

Gambar 4.2 Model SEM

\section{Konversi Path Diagram ke Dalam Persamaan Struktural dan Model Pengukuran}

1. Persamaan Struktural persamaan struktural dalam penelitian ini adalah:
Keberadaan Rumah Kelola Sampah $=\beta 1$ Pengetahuan Masyarakat $+\beta 2$ Sikap Masyarakat $+\beta 3$ Tindakan Masyarakat $+\beta 4$ Keberadaan RKS + Z1

2. Model Pengukuran

Model Pengukuran pada penelitian ini adalah:

Tabel 4.1 Model Pengukuran Konsep Eksogen (Pengetahuan Masyarakat)

\begin{tabular}{|c|}
\hline Konsep Eksogen \\
\hline $\mathrm{X} 1=\lambda 1$ Pengetahuan Masyarakat $+\mathrm{e} 7$ \\
\hline $\mathrm{X} 2=\lambda 2$ Pengetahuan Masyarakat $+\mathrm{e} 6$ \\
\hline $\mathrm{X} 3=\lambda 3$ Pengetahuan Masyarakat $+\mathrm{e} 5$ \\
\hline $\mathrm{X} 4=\lambda 4$ Pengetahuan Masyarakat $+\mathrm{e} 4$ \\
\hline
\end{tabular}

Tabel 4.1 Lanjutan Model Pengukuran Konsep Eksogen (Pengetahuan Masyarakat)

\begin{tabular}{|c|}
\hline Konsep Eksogen \\
\hline $\mathrm{X} 5=\lambda 5$ Pengetahuan Masyarakat $+\mathrm{e} 3$ \\
\hline $\mathrm{X} 6=\lambda 6$ Pengetahuan Masyarakat $+\mathrm{e} 2$ \\
\hline $\mathrm{X} 7=\lambda 7$ Pengetahuan Masyarakat $+\mathrm{e} 1$ \\
\hline
\end{tabular}

(Sumber: Pengolahan Data, 2018)

Tabel 4.2 Model Pengukuran Konsep Eksogen (Sikap Masyarakat)

\begin{tabular}{|c|}
\hline Konsep Eksogen \\
\hline $\mathrm{X} 1=\lambda 1$ Sikap Masyarakat $+\mathrm{e} 14$ \\
\hline $\mathrm{X} 2=\lambda 2$ Sikap Masyarakat $+\mathrm{e} 13$ \\
\hline $\mathrm{X} 3=\lambda 3$ Sikap Masyarakat $+\mathrm{e} 12$ \\
\hline $\mathrm{X} 4=\lambda 4$ Sikap Masyarakat $+\mathrm{e} 11$ \\
\hline $\mathrm{X} 5=\lambda 5$ Sikap Masyarakat $+\mathrm{e} 10$ \\
\hline $\mathrm{X} 6=\lambda 6$ Sikap Masyarakat $+\mathrm{e} 9$ \\
\hline $\mathrm{X} 7=\lambda 7$ Sikap Masyarakat $+\mathrm{e} 8$ \\
\hline
\end{tabular}

(Sumber: Pengolahan Data, 2018)

Tabel 4.3 Model Pengukuran Konsep Eksogen (Tindakan Masyarakat)

\begin{tabular}{|c|}
\hline Konsep Eksogen \\
\hline $\mathrm{X} 1=\lambda 1$ Tindakan Masyarakat $+\mathrm{e} 21$ \\
\hline $\mathrm{X} 2=\lambda 2$ Tindakan Masyarakat $+\mathrm{e} 20$ \\
\hline $\mathrm{X} 3=\lambda 3$ Tindakan Masyarakat $+\mathrm{e} 19$ \\
\hline $\mathrm{X} 4=\lambda 4$ Tindakan Masyarakat $+\mathrm{e} 18$ \\
\hline $\mathrm{X} 5=\lambda 5$ Tindakan Masyarakat $+\mathrm{e} 17$ \\
\hline $\mathrm{X} 6=\lambda 6$ Tindakan Masyarakat $+\mathrm{e} 16$ \\
\hline $\mathrm{X} 7=\lambda 7$ Tindakan Masyarakat $+\mathrm{e} 15$ \\
\hline
\end{tabular}

(Sumber: Pengolahan Data, 2018)

Dibawah ini merupakan tabel pengukuran konsep endogen (Keberadaan Rumah Kelola Sampah):

Tabel 4.4 Model Pengukuran Konsep Endogen (Keberadaan RKS)

\begin{tabular}{|c|}
\hline Konsep Endogen \\
\hline Y1 $=\lambda 1$ Keberadaan RKS + e 22 \\
\hline Y2 $=\lambda 2$ Keberadaan RKS + e 23 \\
\hline Y3 $=\lambda 3$ Keberadaan RKS + e24 \\
\hline
\end{tabular}




\begin{tabular}{|c|}
\hline $\mathrm{Y} 4=\lambda 4$ Keberadaan RKS $+\mathrm{e} 25$ \\
\hline $\mathrm{Y} 5=\lambda 5$ Keberadaan RKS $+\mathrm{e} 26$ \\
\hline $\mathrm{Y} 6=\lambda 6$ Keberadaan RKS $+\mathrm{e} 27$ \\
\hline $\mathrm{Y} 7=\lambda 7$ Keberadaan RKS $+\mathrm{e} 28$ \\
\hline (Sumber: Pengolahan Data, 2018 )
\end{tabular}

\section{Mengidentifikasi Model Struktural}

Sebagai dasar dalam identifikasi model, nilai degrees of freedom ( $d f$ ) digunakan sebagai acuan. Nilai $d f$ dalam output software AMOS yaitu sebagai berikut:

\begin{tabular}{|rr}
\hline $\begin{array}{l}\text { Notes for Model (Default model) } \\
\text { Computation of degrees of freedom (Default model) }\end{array}$ \\
Number of distinct sample moments: & 406 \\
Number of distinct parameters to be estimated: & 60 \\
Degrees of freedom (406 - 60): & 346
\end{tabular}

Gambar 4.3 Nilai Degrees of Freedom Model Awal Karena nilai $d f$ positif maka model adalah overidentified dan pengujian pada model dapat dilakukan.

\section{Melakukan Interpretasi dan Modifikasi Model}

Modifikasi model bertujuan untuk melihat apakah modifikasi yang dilakukan dapat menurunkan nilai chi-square seperti yang kita ketahui semakin kecil nilai chi-square menunjukkan semakin fit model tersebut dengan data yang ada. Sebuah indikator menunjukkan validitas konvergen yang signifikan jika memiliki nilai critical ratio sebesar $>2$. Hal ini menunjukkan bahwa indikator-indikator yang digunakan secara valid mengukur apa yang seharusnya diukur dalam model.

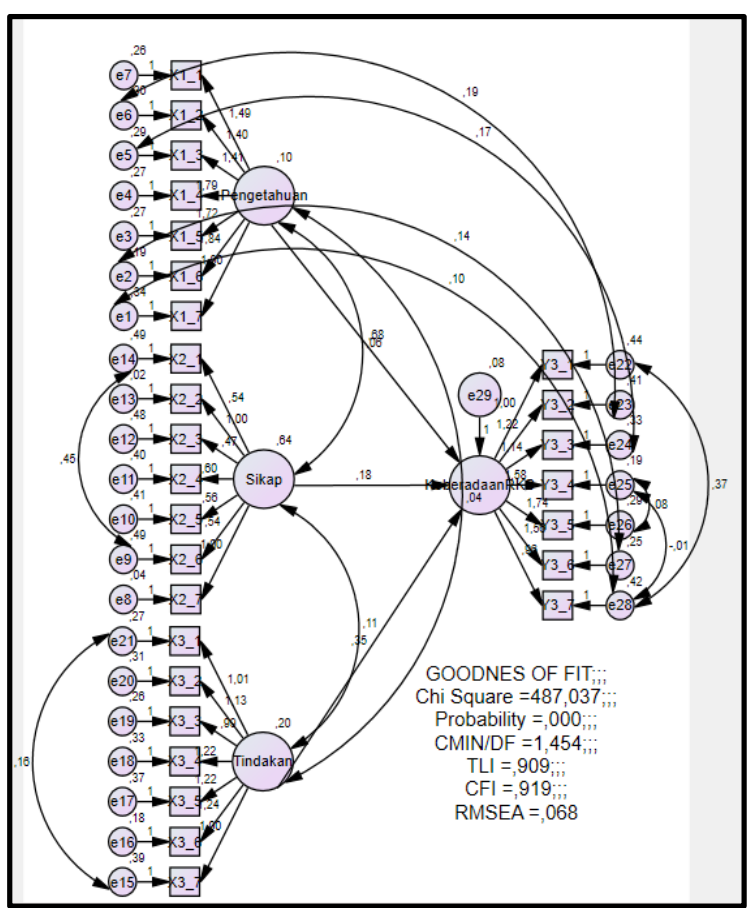

Gambar 4.4 Model SEM Stelah Modifikasi Gambar 4.4 adalah model SEM setelah modifikasi, terlihat bahwa nilai chi-square setelah modifikasi sebesar 487,037 sedangkan nilai chi-square sebelum modifikasi sebesar 975,456 ini artinya nilai chi-square setelah modifikasi lebih kecil atau berkurang dari sebelumnya.

\begin{tabular}{|c|c|c|c|c|c|c|c|}
\hline & & & Estimate & S.E. & C.R. & $\mathrm{P}$ & Label \\
\hline KeberadaanRKS & $<--$ & Pengetahuan & 680 & 207 & 3,282 &, 001 & par_25 \\
\hline KeberadaanRKS & $<--$ & Sikap &, 178 & 054 & 3,321 & $* * *$ & par_26 \\
\hline KeberadaanRKS & $<--$ & Tindakan & 350 &, 115 & 3,051 &, 002 & par_27 \\
\hline $\mathrm{X} 1 \_7$ & $<--$ & Pengetahuan & 1,000 & & & & \\
\hline $\mathrm{X} 1 \_6$ & $<--$ & Pengetahuan & 1,844 & 396 & 4,656 & *** & par_1 \\
\hline X1_5 & $<--$ & Pengetahuan & 1,724 & ,391 & 4,405 & $* * *$ & par_2 \\
\hline X1_4 & $<--$ & Pengetahuan & 1,792 & 402 & 4,455 & *** & par_3 \\
\hline $\mathrm{X} 1 \_3$ & $<--$ & Pengetahuan & 1,405 &, 326 & 4,312 & *** & par_4 \\
\hline X1_2 & $<--$ & Pengetahuan & 1,402 & 325 & 4,317 & *** & par_5 \\
\hline X1_1 & $<--$ & Pengetahuan & 1,490 & 342 & 4,363 & *** & par_6 \\
\hline $\mathrm{X} 2{ }_{-} 7$ & $<--$ & Sikap & 1,000 & & & & \\
\hline $\mathrm{X} 2 \_6$ & $<--$ & Sikap &, 543 & 090 & 6,016 & *** & par_7 \\
\hline $\mathrm{X} 2 \_5$ & $<--$ & Sikap &, 564 &, 083 & 6,836 & *** & par_8 \\
\hline $\mathrm{X} 2 \_4$ & $<--$ & Sikap & 605 & 082 & 7,365 & *** & par_9 \\
\hline $\mathrm{X} 2{ }_{3} 3$ & $<--$ & Sikap & ,469 & .089 & 5,263 & *** & par_10 \\
\hline $\mathrm{X} 2 \_2$ & $<--$ & Sikap & ,998 & 035 & 28,909 & *** & par_11 \\
\hline $\mathrm{X} 2 \_1$ & $<--$ & Sikap & 541 &, 091 & 5,977 & *** & par_12 \\
\hline $\mathrm{X} 3{ }_{-} 7$ & $<--$ & Tindakan & 1,000 & & & & \\
\hline $3 \_6$ & $<--$ & Tinda & 236 &, 226 & 5,468 & *** & par_13 \\
\hline $\mathrm{X} 3 \_5$ & $<--$ & Tinda & 1,223 & 244 & 5,011 & $* * *$ & par_14 \\
\hline $\mathrm{X} 3 \_4$ & $<--$ & Tindakan & 1,215 & 245 & 4,956 & *** & par_15 \\
\hline $\mathrm{X} 3{ }_{3} 3$ & $<--$ & Tindakan & ,989 & 200 & 4,939 & $* * *$ & par_16 \\
\hline X3_2 & $<--$ & Tindakan & 1,127 &, 220 & 5,125 & *** & par_17 \\
\hline X3_1 & $<--$ & Tindakan & 1,012 & 147 & 6,903 & *** & par_18 \\
\hline Y3_ & $<--$ & $\mathrm{Ke}$ & 1,000 & & & & \\
\hline Y3_2 & $<--$ & Keber & 1,222 &, 231 & 5,291 & *** & par_19 \\
\hline Y3_3 & $<--$ & Keber & 1,138 & 212 & 5,379 & $* * *$ & par_20 \\
\hline Y3_4 & $<--$ & KeberadaanRKS & 1,581 &, 274 & 5,765 & $* * *$ & par_21 \\
\hline Y3_5 & $<--$ & KeberadaanRKS & 1,737 & 303 & 5,733 & $* * *$ & par_22 \\
\hline Y3_6 & $<--$ & KeberadaanRKS & 1,561 &, 263 & 5,943 & *** & par_23 \\
\hline Y3_7 & $<--$ & KeberadaanRKS & 956 & 078 & 12,267 & *** & par_24 \\
\hline
\end{tabular}

Gambar 4.5 Regression Weights Setelah Modifikasi 
Dari hasil regression weights seperti gambar 4.5 diatas terlihat bahwa semua indikator sudah signifikan, ditandai dengan adanya critical ratio $>2$ dan $\mathrm{P}<0,005$.

\section{Evaluasi Kriteria Goodness Of Fit}

Evaluasi model dilakukan melalui uji kesesuaian dan statistik, serta uji reliabilitas. Dalam uji kesesuaian dan statistik dilakukan dengan menggunakan beberapa Fit Index untuk mengukur kebenaran model yang diajukan. Hasil evaluasi dari masing-masing model yang dimodifikasi ini dibandingkan dengan batasan statistik yang telah ditetapkan dalam prosedur SEM. Adapun hasil uji Goodness Of Fit Indexes pada penelitian ini adalah sebagai berikut:

Tabel 4.5 Rekapitulasi Evaluasi Goodness of Fit

\begin{tabular}{|c|c|c|c|}
\hline Kriteria & $\begin{array}{l}\text { Cut of } \\
\text { Value }\end{array}$ & Hasil & Evaluasi \\
\hline Chi Square & $\begin{array}{c}\text { Diharapkan } \\
\text { Kecil }\end{array}$ & 487,037 & Baik (Fit) \\
\hline Probability & $<0,05$ & 0,000 & Baik (Fit) \\
\hline CMIN/DF & $<2,00$ & 1,454 & Baik (Fit) \\
\hline GFI & $\begin{array}{c}\text { Mendekati } \\
1 \\
\end{array}$ & 0,751 & Baik (Fit) \\
\hline TLI & $>0,90$ & 0,909 & Baik (Fit) \\
\hline CFI & $\begin{array}{c}\text { Mendekati } \\
1\end{array}$ & 0,919 & Baik (Fit) \\
\hline RMSEA & $<0,08$ & 0,068 & Baik (Fit) \\
\hline NFI & $\begin{array}{c}\text { Mendekati } \\
1\end{array}$ & 0,785 & Baik (Fit) \\
\hline
\end{tabular}

Berdasarkan Tabel 4.5 diketahui bahwa nilai Goodness of Fit Indexes dari model penelitian ini dari semua kriteria telah terpenuhi dengan baik maka dapat disimpulkan bahwa model yang dibuat telah sesuai dengan data observasi.

\section{Hasil Pengujian Metode SEM}

Uji hipotesis ini dilakukan guna mengetahui apakah berpengaruh atau tidaknya variabel eksogen terhadap variabel endogen. Hipotesis ini dapat diterima jika nilai probabilitasnya adalah sebesar $\mathrm{P}$ $<0,05$ dan nilai Critical Ratio (CR) sebesar $>1,96$.

Tabel 4.6 Regression Weights Estimates Software AMOS 20

\begin{tabular}{|l|c|c|}
\hline & C.R & P \\
\hline KeberadaanRKS - Pengetahuan & 3,282 &, 001 \\
\hline Keberadaan RKS - Sikap & 3,321 & $* * *$ \\
\hline Keberadaan RKS - Tindakan & 3,051 &, 002 \\
\hline (Sumber: Pengolahan Data, 2018)
\end{tabular}

Dasar Keputusan:

Jika nilai Probability $(\mathrm{P})>0,05$ maka $\mathrm{H}_{0}$ diterima $\mathrm{H}_{1}$ ditolak, Jika nilai Probability $(\mathrm{P})<0,05$ maka $\mathrm{H}_{0}$ ditolak $\mathrm{H}_{1}$ diterima.

Berdasarkan Tabel 4.5 diperoleh keterangan hasil pengujian hipotesis sebagai berikut:

1. Keberadaan RKS - Pengetahuan, terlihat bahwa nilai $\mathrm{P} 0,001<0,05$. Nilai tersebut jauh dibawah 0,05 , maka dinyatakan $\mathrm{H}_{1}$ diterima. Jadi dapat dikatakan adanya pengaruh positif dan signifikan antara pengetahuan masyarakat terhadap keberadaan RKS.

2. Keberadaan RKS - Sikap, terlihat bahwa nilai P $0,000<0,05$. Nilai tersebut jauh dibawah 0,05 , maka dinyatakan $\mathrm{H}_{1}$ diterima. Jadi dapat dikatakan adanya pengaruh positif dan signifikan antara sikap masyarakat terhadap keberadaan RKS.

3. Keberadaan RKS - Tindakan, terlihat bahwa nilai $\mathrm{P} 0,001<0,05$. Nilai tersebut jauh dibawah 0,05 , maka dinyatakan $\mathrm{H}_{1}$ diterima. Jadi dapat dikatakan adanya pengaruh positif dan signifikan antara tindakan masyarakat terhadap keberadaan RKS.

\section{Analisis Pengembangan Model Berdasarkan Teoritis \\ Pengembangan model berdasarkan teoritis bertujuan untuk melihat hubungan keterkaitan antar variabel yang ada secara teoritis. Pada penelitian ini diperoleh 4 variabel dengan 28 indikator, dimana setiap variable mempunyai 7 indikator. Meskipun dalam kondisi yang sebenarnya sangat banyak sekali faktor yang mempengaruhi variabel dan indikator tersebut. akan tetapi faktor-faktor yang ada ini diharapkan dapat mewakili kondisi nyata.}

\section{Analisis Pengembangan Path Diagram}

Setelah terhubung antara variabel bebas dan variabel terikat maka akan dapat dilihat hubungan kausalitas antara tiap variabel ke variabel lain dan indikator ke variabel konstruk dan setiap konstruk atau indikator diberikan nilai error dimana pemberian nilai error bertujuan untuk memberikan toleransi kesalahan yang mungkin akan terjadi, kesalahan ataupun penyimpangan ini bisa jadi disebabkan oleh indikator yang ada belum dapat mewakili dan merefleksikan kondisi yang ada dilapangan.

Pada model tampak banyak angka "1" dimana angka tersebut akan muncul secara otomatis saat membuat tambahan sebuah variabel error. Dengan demikian semua variabel error akan diberi nilai 
parameter yang telah ditetapkan atau disebut fixed parameter yaitu 1.

Analisis Konversi Path Diagram ke Dalam Persamaan Struktural dan Model Pengukuran

1. Persamaan Struktural

Persamaan Keberadaan Rumah Kelola Sampah

$=\beta 1$ Pengetahuan Masyarakat $+\beta 2$ Sikap Masyarakat $+\beta 3$ Tindakan Masyarakat $+\beta 4$ Keberadaan RKS + Z1 merupakan variabel persamaan secara struktural, dimana dalam prosesnya besaran nilai $\beta 1, \beta 2, \beta 3$ yang merupakan konstanta dari variabel pengetahuan masyarakat, sikap masyarakat, dan tindakan masyarakat akan secara konstan selalu berpengaruh terhadap variabel $\beta 4$ keberadaan RKS dan juga dengan adanya pemberian nilai error sedikit banyaknya juga berpengaruh terhadap hasil yang akan didapatkan nantinya, meskipun pemberian nilai error ini hanya sebagai langkah antisipasi ataupun toleransi jika terjadi penyimpangan atau kesalahan seperti yang telah disebutkan diatas.

2. Persamaan Model Pengukuran

Tujuan dari Persamaan model pengukuran untuk melihat sejauh mana hubungan antara variabel dan masing-masing indikatornya yang nantinya dilihat berdasarkan outputnya misalnya persamaan $\mathrm{X} 1=\lambda 1$ pengetahuan masyarakat $+\mathrm{e} 7$, dimana persamaan ini menyatakan keterkaitan antara variabel pengetahuan masyarakat dengan indikator 1, dimana besar atau kecilnya nilai $\lambda$ pada persamaan nantinya juga akan berpengaruh terhadap keputusan yang akan diambil dan juga untuk mengetahui bagaimana nilai keterkaitan ini harus melalui beberapa tahapan.

\section{Analisis Identifikasi Model Struktural}

Berdasarkan model awal yang telah dibuat dapat diketahui bahwa nilai $d f$ yang diperoleh sebesar 346 , hal ini disebabkan oleh banyaknya indikator yang ada, sehingga jumlah $d f$ juga besar. Dapat disimpulkan bahwa model pada penelitian ini termasuk kategori over identified karena $d f$ bernilai positif yaitu sebesar 346. Kemudian setelah dilakukan modifikasi nilai $d f$ berubah menjadi 335 dan tetap positif. Hal ini berarti model memiliki cukup informasi atau bisa dilanjutkan untuk mengidentifikasi adanya solusi.

\section{Analisis Interpretasi dan Modifikasi Model}

Modifikasi model dilakukan dengan menghubungkan tingkat error sesuai perintah dari output software AMOS. Modifikasi model dibuat agar mudah dilakukan penyesuaian pada Modification indices. Fungsinya adalah untuk dapat mempermudah memodifikasi model SEM sehingga dapat disesuaikan pada model SEM yang telah dibuat sebelumnya. Sebagai contoh e25 dihubungkan ke e28, sehingga dapat menurunkan nilai chi-square pada model SEM setelah modifikasi. Setelah modifikasi nilai chi-square menurun sebesar 487,037 dari 975,458 artinya nilai chi-square setelah modifikasi lebih kecil atau berkurang dari sebelumnya.

Berdasarkan output Regression Weights setelah modifikasi, semua indikator sudah berada dikategori valid atau signifikan sehingga dapat disimpulkan bahwa indikator-indikator yang sudah signifikan ialah responden mengerti dan paham terhadap pernyataaan yang diajukan didalam kuesioner.

\section{Analisis Kriteria Goodness of Fit}

Pada analisa kriteria goodness of fit ini akan dilakukan analisa terhadap nilai chi square, probability, $d f$, CMIN/DF, GFI, TLI, CFI, RMSEA, dan NFI. Nilai chi square merupakan nilai yang menggambarkan tingkatan ataupun kondisi dalam penelitian yang dilakukan. Dari semua hasil uji tersebut menujukkan kecocokan yang baik (good fit) karena sebagian besar uji kecocokan menunjukkan model fit maka dapat disimpulkan bahwa model yang digunakan dalam penelitian ini dapat dijadikan dasar analisa terhadap permasalahan penelitian ini.

\section{Kesimpulan}

Berdasarkan penelitian dan hasil pengolahan data dapat diambil kesimpulan sebgai berikut:

1. Untuk variabel pengetahuan masyarakat memiliki hubungan yang sangat signifikan terhadap keberadaan RKS. Pengetahuan masyarakat memberikan nilai positif dan memiliki peluang besar dalam mempengaruhi minat masyarakat untuk mengelola sampah di Rumah Kelola Sampah. Masyarakat harus selalu diberikan edukasi mengenai pentingnya mengolah sampah menjadi produk-produk yang bermanfaat. Selain itu dengan mengolah sampah-sampah yang ada dilingkungan dapat menciptakan lingkungan yang bersih dan sehat sehingga terbebas dari kuman dan penyakit. 
2. Untuk variabel sikap masyarakat memiliki hubungan yang sangat signifikan terhadap keberadaan RKS. Sikap masyarakat memberikan nilai positif dan memiliki peluang besar dalam mempengaruhi minat masyarakat untuk mengelola sampah di Rumah Kelola Sampah. Faktor pendukung terwujudnya suatu sikap antara lain, fasilitas, dukungan dari pihak lain, pengalaman serta lingkungan dan motivasi. Sikap masyarakat dalam pengelolaan sampah di RKS dengan cara mengelola sampah dilakukan setiap hari, memanfaatkan sampah sisa makanan yang dapat diolah menjadi pupuk, memanfaatkan sampahsampah plastik yang dapat diolah menjadi suatu produk kerajinan tangan sehingga masyarakat dapat mengetahui bahwa kebersihan lingkungan sangat pnting karena dapat memberikan keuntungan yang banyak bagi masyarakat.

3. Untuk variabel tindakan masyarakat memiliki hubungan yang sangat signifikan terhadap keberadaan RKS. Tindakan masyarakat memberikan nilai positif dan memiliki peluang besar dalam mempengaruhi minat masyarakat untuk mengelola sampah di Rumah Kelola Sampah. Tindakan masyarakat dengan adanya RKS yaitu mengikuti penyuluhan atau sosialisai mengenai pengelolaan sampah yang dilakukan oleh pengurus RKS, mengikuti kegiatan kebersihan seperti kerja bakti. Apabila tindakan ini dilakukan masyarakat dapat mewujudkan minat masyarakat untuk mengatasi permasalahan pengurangan jumlah sampah yang dihasilkan manusia.

4. Rancangan usulan perbaikan pada penelitian ini untuk memberikan usulan yang baik guna meningkatkan partisipasi dan minat masyarakat dalam melakukan pengelolaan sampah. Adapun rancangan usulan perbaikan yang diberikan peneliti pada Rumah Kelola Sampah (RKS) di Kelurahan Tangkerang Barat adalah sebagai berikut:

a. Melakukan sosialisasi terhadap masyarakat yang berada di Kelurahan Tangkerang Barat guna meningkatkan partisipasi masyarakat dan mengetahui tujuan dari program Rumah Kelola Sampah (RKS)

b. Menjelaskan Visi dan Misi dari Rumah Kelola Sampah (RKS)

c. Menjelaskan Visi dan Misi dari Rumah Kelola Sampah (RKS)

d. Melakukan evaluasi seminggu sekali untuk melihat hasil yang di dapat dari mengelola sampah di RKS. Apabila sudah menghasilkan dapat dimanfaatkan untuk warga sekitar Kelurahan Tangkerang Barat.

e. Memberikan instruksi kerja kepada pengurus RKS seperti melakukan sosialisasi, evaluasi setiap minggu, dan mengajak masyarakat untuk berpartisipasi.

f. Mengelola sampah seharusnya tidak hanya dari jenis sampah organik saja melainkan jenis sampah anorganik dapat juga di manfaatkan, karena sampah anorganik apabila di kelola dapat mengasilkan suatu kerajinan tangan dan sampahnya pun tidak basah dan kotor sedangkan jenis sampah organik masyarakat lebih malas mengelola dikarenakan basah, bau dan kotor.

g. Membentuk anggota pada setiap pengelolaan jenis sampah organik dan anorganik. Misalnya, pada pengelolaan jenis sampah organik ada beberapa anggota untuk mengevaluasi proses kerja pengelolaan sampah organik, hasilnya akan dipersentasikan setiap setahun sekali. Selanjutnya pada pengelolaan jenis sampah anorganik juga ada beberapa anggota pengurusnya untuk melihat dan mengevaluasi proses kerja pengelolaan sampah anorganik, hasilnya juga akan di persentasikan setiap setahun sekali.

h. Anggota pengurus dari masing-masing pengelolaan jenis sampah organik ataupun anorganik mengajak masyarakat untuk melakukan gotong royong bersama mengumpulkan sampah dan memilahnya sesuai jenis sampahnya masing-masing. Hal ini dapat dilakukan seminggu sekali.

\section{Daftar Pustaka}

[1] Dewanto Kuncoro. Pelaksanaan Program Pelatihan Pengelolaan Sampah Di Rumah Pintar Nur Aini, Kabupaten Gunungkidul, Daerah Istimewa Yogyakarta. Universitas Negeri Yogyakarta, Yogyakarta, 2017.

[2] Fadhilah Arief, Sugianto Heri, Hadi Kuncoro, Firmandhani Wahyu Satriya, Murtini Woro Titien, Pandelaki Endrianto Edward. Kajian Pengelolaan Sampah Kampus Jurusan Arsitektur Fakultas Teknik Universitas Diponegoro. Universitas Diponegoro, Semarang, 2013. 
[3] Garini Ardya. Pengetahuan, Sikap, dan Perilaku Siswa Sekolah Dasar Negeri Terhadap Pengelolaan Sampah di Kecamatan Bantar Gebang Kota Bekasi Tahun 2012. Universitas Indonesia, Depok, 2012.

[4] Ikhsandri. Kajian Infrastruktur Pengolahan Sampah di Kawasan Berkembang Jakabaring Kelurahan 15 ULU Kota Palembang, Universitas Sriwijaya, Sumatera Selatan, 2014.

[5] Jumar, Fitriyah Nur, Kalalinggi Rita. Strategi Pengelolaan Sampah Rumah Tangga di Kelurahan Lok Bahu Kecamatan Sungai Kunjang Kota Samarinda, Universitas Mulawarman, Samarinda, 2014.

[6] Kasanah Aprilia. Penggunaan Metode Structural Equation Modeling Untuk Analisis Faktor Yang Mempengaruhi Kualitas Pelayanan Perpustakaan Dengan Program Lisrel 8.80, Universitas Negeri Semarang, Semarang, 2015.

[7] Nawangsari Yunita Albertin. Structural Equation Modeling Pada Perhitungan Indeks Kepuasan Pelanggan Dengan Menggunakan Software Amos, Universitas Negeri Yogyakarta, Yogyakarta, 2011.

[8] Iskandar, Efendi dan Syamsu Rizal. Metode Depresiasi Aktiva Tetap Berwujud dan Dampaknya pada Laporan Laba Rugi. Jurnal Akuntansi \& Keuangan Volume 2 Nomor 1. Jakarta. 2011.

[9] Pungchompoo Sirirat, Mori Takayuki, Sopadang Apichat. Comparison of Different Prioritization Methods in the Combination Methods of the Structural Equation Modelling (SEM) and Analytical Hierarchy Process (AHP) on the Performance Measurement of a Thai Frozen Shrimp Supply Chain, Universitas Tsinghua, Beijing, 2014.

[10] Rahman Sandi. Pengaplikasian Metode Structural Equation Modelling Untuk Meningkatkan Kinerja Karyawan, Universitas Islam Negeri Sultas Syarif Kasim Riau, Pekanbaru, 2016.

[11] Schreiber B. James, Stage K. Frances, King Jamie, Nora Amaury, Barlow A. Elizabeth. Reporting Structural Equation Modeling And Confirmatory Factor Analysis Results: A Review, University of Houston, Texas, 2006.

[12] Santoso Singgih. AMOS 22 Untuk Structural Equation Modelling. Jakarta, 2015.

[13] Yamin Sofyan, Kurniawan Heri. Structural Equation Modeling, Jakarta, 2009. 